\title{
HUBUNGAN PENGETAHUAN DAN SIKAP DENGAN STATUS BEBAS BUANG AIR BESAR SEMBARANGAN DI DESA AMBENGAN, KECAMATAN SUKASADA KABUPATEN BULELENG TAHUN 2021
}

\begin{abstract}
A A Wulan Krisnu Putri ${ }^{1}$, Nengah Notes ${ }^{2}$
Abstract : ODF (Open Defecation Free) or Free Defecation is a village/kelurahan where $100 \%$ of the people have defecated in healthy latrines. Ambengan Village is one of the villages that has not been ODF in Buleleng Regency. There are $89.6 \%$ who are ODF and $10.4 \%$ are not ODF from 1,278 households in Ambengan village. The purpose of this study was to determine the relationship between knowledge and attitudes with the Free Status of Open Defecation. This study uses a cross-sectional design with a sample of 93 respondents and data analysis using the Chi-Square statistical test. Respondents with good knowledge (45.2\%), moderate (36.6\%) and less (18.3\%). Respondents with good attitude (43\%), moderate (37.6\%) and less (19.4\%). The results of the Chi Square test showed that there was a relationship between the respondent's knowledge $(p=0.000)$ and the respondent's attitude $(p=0.000)$ with the status of free defecation. It can be concluded that there is a relationship between knowledge and attitude with open defecation free status in Ambengan village. Public health center to carry out counseling about ODF (Open Defecation Free) to the community and villages can make rules regarding the prohibition of open defecation.
\end{abstract}

Keywords: Knowledge, Attitude and Open Defecation Free Status

\section{PENDAHULUAN}

Sanitasi Total Berbasis Masyarakat (STBM) adalah pendekatan yang digunakan untuk merubah perilaku hygiene dan sanitasi melalui pemberdayaan masyarakat dengan metode pemicuan. Dengan metode pemicuan, STBM diharapkan dapat merubah perilaku kelompok masyarakat dalam upaya memperbaiki keadaan sanitasi lingkungan mereka, sehingga tercapai kondisi Open Defecation Free (ODF), pada suatu komunitas atau desa. Suatu desa dikatakan ODF jika 100\% penduduk desa tersebut mempunyai akses BAB di jamban sehat. Desa ODF disebut juga dengan desa SBS (Stop Buang Air Besar Sembarangan) atau Bebas Buang Air Besar Sembarangan ${ }^{1}$. 
Permasalahan kesehatan lingkungan yang mendominasi adalah masalah sanitasi. Tantangan pembangunan sanitasi di Indonesia adalah sosial budaya dan perilaku penduduk yang terbiasa buang air besar di sembarang tempat, khususnya ke badan air yang juga digunakan untuk mencuci, mandi dan kebutuhan lainnya 2 . Berdasarkan pendekatan teori Lawrence Green yang dikutip, terdapat beberapa faktor yang mempengaruhi masyarakat untuk $\mathrm{BAB}$ dijamban dalam pencapaian ODF adalah faktor predisposis yang meliputi pengetahuan dan sikap. Pengetahuan merupakan hasil dari tahu, dan ini terjadi setelah orang melakukan pengindraan terhadap suatu objek tertentu. Sikap merupakan reaksi atau respon yang masih tertutup dari seseorang terhadap suatu stimulus atau objek ${ }^{3}$. Perilaku Buang Air Besar sembarangan (BABS/Open defecation) termasuk salah satu contoh perilaku yang tidak sehat. BABS/Open defecation adalah suatu tindakan membuang kotoran atau tinja di tempat terbuka : ladang, hutan, semak-semak, sungai, pantai atau area terbuka lainnya dan jika dibiarkan dapat menimbulkan pencemaran lingkungan, tanah, udara, air serta menimbulkan penyakit ${ }^{4}$.

Berdasarkan data dari Kementerian Kesehatan per November 2018, desa/kelurahan dengan status SBS terverifikasi yaitu sebanyak 16.194 desa/kelurahan (20.04 \%) dari total 80.805 desa/kelurahan di Indonesia. Provinsi dengan persentase tertinggi desa/kelurahan SBS terverifikasi adalah DI Yogyakarta (100\%), sedangkan Provinsi yang persentase desa/kelurahan SBS terverifikasi terendah adalah Provinsi Maluku dengan $1 \%$ desa/kelurahan SBS terverifikasi. Di Provinsi Bali, ada sebanyak 285 desa yang sudah ODF dari 716 jumlah desa yang ada ${ }^{5}$.

Berdasarkan data dari Dinas Kesehatan Kabupaten Buleleng per Januari 2021, ada sebanyak 23 desa yang ada di Kabupaten Buleleng telah mendeklarasikan desanya menjadi desa Open Defecation Free (ODF) atau stop buang air besar sembarangan. Desa Ambengan merupakan salah satu desa yang ada di Kecamatan Sukasada, Kabupaten Buleleng. Desa Ambengan merupakan salah satu desa yang belum ODF di Kabupaten Buleleng ${ }^{6}$. 
Menurut data puskesmas Sukasada II tahun 2020, ada 133 kk atau $10,4 \%$ yang masih buang air besar sembarangan di desa Ambengan dan juga ada kejadian diare sebanyak 22 kasus. Dari hasil pendataan, masih adanya masyarakat yang buang air besar di sembarang tempat seperti di sungai, karena mereka menganggap buang air besar di sungai lebih praktis. Berdasarkan hasil penyuluhan yang dilakukan oleh petugas kesehatan lingkungan di Puskesmas tentang STBM dan termasuk ODF di dalamnya, masih banyak masyarakat yang tidak mengetahui tentang ODF. Hasil pengukuran dengan menggunakan kuesioner pengukuran pengetahuan tentang ODF, terdapat 95 orang yang belum mengetahui tentang ODF dari 100 orang yang diberikan penyuluhan. Kurangnya pengetahuan masyarakat mengenai ODF, akan berpengaruh pada perilaku BAB yang buruk ${ }^{7}$.

\section{METODE PENELITIAN}

Jenis penelitian ini adalah penelitian obeservasional analitik yang bertujuan untuk mengetahui hubungan antar variabel dependen dan independen. Pendekatan yang digunakan pada penelitian ini adalah cross sectional, yaitu pengukuran yang dilakukan pengamatan sesaat atau dalam suatu periode tertentu dan setiap subjek studi hanya dilakukan satu kali pengamatan selama penelitian ${ }^{8}$.

Sampel dalam penelitian ini adalah masyarakat desa Ambengan yang berjumlah 93 orang. Analisis data menggunakan analisis univariat dan analisis bivariat. Analisis univariat dilakukan untuk menggambarkan distribusi frekuensi masing-masing variabel, baik variabel bebas, variabel terikat dan karakteristik responden. Analisis bivariat digunakan untuk mengetahui hubungan antara pengetahuan dan sikap dengan status Bebas Buang Air Besar Sembarangan. Uji statistika yang digunakan yaitu $C h i$ square. ${ }^{8}$. 
HASIL DAN PEMBAHASAN

1. Tingkat

Pengetahuan

Responden

Tabel 1

Distribusi Responden

Berdasarkan Pengetahuan dengan Status Bebas BABS

\begin{tabular}{ccc}
\hline Pengetahuan & Frekuensi & $\begin{array}{c}\text { Persen } \\
(\mathbf{\%})\end{array}$ \\
\hline Baik & 42 & 45,2 \\
Sedang & 34 & 36,5 \\
Kurang & 17 & 18,3 \\
\hline Jumlah & $\mathbf{9 3}$ & $\mathbf{1 0 0}$ \\
\hline
\end{tabular}

Hasil penelitian menunjukkan bahwa tingkat pengetahuan responden dalam kategori baik sebanyak 42 orang $(45,2 \%)$, tingkat pengetahuan responden dalam kategori sedang sebanyak 34 orang $(36,6 \%)$ dan tingkat pengetahuan responden dalam kategori kurang sebanyak 17 orang (18,3\%).

Tingkat pengetahuan erat kaitannya dengan pendidikan, semakin tinggi tingkat pendidikan maka tingkat pengetahuan seseorang akan semakin baik. Seseorang yang berpendidikan tinggi akan mempunyai pengetahuan yang lebih luas dibandingkan dengan seseorang yang tingkat pendidikannya rendah. Pendidikan diperlukan untuk mendapatkan informasi misalnya hal-hal yang menunjang kesehatan sehingga meningkatkan kualitas hidup. Pendidikan juga dapat mempengaruhi seseorang dalam berperilaku. Pada umumnya semakin tinggi pendidikan seseorang makan semakin mudah untuk menerima informasi ${ }^{9}$.

Pengetahuan tentang ODF atau Bebas Buang Air Besar Sembarangan sangat penting untuk ditanamkan pada masyarakat. Salah satu cara meningkatkan pengetahuan adalah dengan cara memberikan penyuluhan. Dalam hal ini peran petugas kesehatan sangat penting untuk memberikan penyuluhan kepada masyarakat sehingga informasi tentang kesehatan tersampaikan ke masyarakat khususnya tentang ODF / Bebas Buang Air Besar Sembarangan. 


\section{Sikap Responden}

Tabel 2

Distribusi Responden

Berdasarkan Sikap dengan Status Bebas BABS

\begin{tabular}{ccc}
\hline Sikap & Frekuensi & $\begin{array}{c}\text { Persen } \\
(\boldsymbol{\%})\end{array}$ \\
Baik & 40 & 43,0 \\
Sedang & 35 & 37,6 \\
Kurang & 18 & 19,4 \\
Jumlah & $\mathbf{9 3}$ & $\mathbf{1 0 0}$ \\
\hline
\end{tabular}

Hasil penelitian menunjukkan bahwa sikap responden dalam kategori baik sebanyak 40 orang (43,0\%), dalam kategori sedang sebanyak 35 orang $(37,6 \%)$ dan dalam kategori kurang sebanyak 18 orang $(19,4 \%)$.

Terwujudnya sikap menjadi suatu tindakan, diperlukan suatu kondisi yang memungkinkan seseorang dapat menerapkan apa yang sudah ia ketahui. Artinya pengetahuan atau sikap yang baik belum tentu mewujudkan suatu tindakan yang baik. Karena perubahan sikap ke arah yang lebih baik akan mempengaruhi terjadinya peran serta masyarakat yang merupakan modal utama keberhasilan program kesehatan ${ }^{10}$

Walaupun sebagian besar masyarakat yang bersikap baik, namun masih ada juga masyarakat yang bersikap kurang baik. Menurut hasil wawancara, masih ada tanggapan masyarakat bahwa BAB di sungai lebih nyaman daripada BAB di jamban tanpa mengetahui penyakit yang akan ditimbulkan dari buang air besar sembarangan. Hal ini mungkin dipengaruhi oleh rendahnya pengetahuan mereka mengenai pemanfaatan jamban sehat.

\section{Hubungan Pengetahuan responden} dengan Status Bebas Buang Air Besar Sembarangan (BABS)

Tabel 3

Hubungan Tingkat Pengetahuan Responden Mengenai Status Bebas Buang Air Besar Sembarangan

\begin{tabular}{ccc}
\hline & \multicolumn{2}{c}{ Status Bebas Buang } \\
Variabel & \multicolumn{2}{c}{ Air Besar } \\
& \multicolumn{2}{c}{ Sembarangan } \\
& $p$ & $\mathrm{X} 2$ \\
Pengetahuan & 0,000 & $39.773^{\mathrm{a}}$ \\
\hline
\end{tabular}

Dari hasil uji statistik dengan menggunakan Chi Square, diperoleh nilai $p=0,000$ dan nilai $\mathrm{x} 2=39.773^{\mathrm{a}}$, karena nilai $p<0,05$ maka Ha diterima dan $\mathrm{H}_{0}$ ditolak, artinya ada hubungan 
yang bermakna antara
pengetahuan responden dengan
status bebas BABS di desa
Ambengan, Kecamatan Sukasada,
Kabupaten Buleleng.

Penelitian ini sejalan dengan hasil penelitian dalam jurnal yang berjudul "Hubungan Pengetahuan, Sikap BAB, Dan Kepemilikan Septic Tank Dengan Status ODF (Open Defecation Free) Di Kecamatan Candisari Kota Semarang", menunjukkan bahwa terdapat hubungan antara pengetahuan dengan status ODF (Bebas Buang Air Besar Sembarangan) dari hasil uji statistik didapatkan bahwa nilai $p=0,029$. Dalam hal ini peran petugas kesehatan, tokoh masyarakat, agama serta pihak-pihak terkait, sangat penting untuk meningkatkan kegiatan penyuluhan untuk meningkatkan pengetahuan masyarakat tentang pentingnya BAB di jamban dan dampak dari perilaku BABS sehingga nantinya bisa tercapai status bebas BABS.

\section{Hubungan sikap responden dengan Status Bebas Buang Air Besar Sembarangan (BABS)}

Tabel 4

Hubungan Sikap Responden

Mengenai Status Bebas Buang Air

Besar Sembarangan

\begin{tabular}{ccc}
\hline Variabel & \multicolumn{2}{c}{$\begin{array}{c}\text { Status Bebas Buang Air } \\
\text { Besar Sembarangan }\end{array}$} \\
& $p$ & $\mathrm{X} 2$ \\
Pengetahuan & 0,000 & $77.635^{\mathrm{a}}$ \\
\hline
\end{tabular}

Dari hasil uji statistik dengan menggunakan Chi Square, diperoleh nilai $p=0,000$ dan nilai $\mathrm{x} 2=77.635^{\mathrm{a}}$, karena nilai $p<0,05$ maka Ha diterima dan $\mathrm{H}_{0}$ ditolak, artinya ada hubungan yang bermakna antara sikap responden dengan status bebas BABS di desa Ambengan, Kecamatan Sukasada, Kabupaten Buleleng. Penelitian ini sejalan dengan hasil penelitian dalam jurnal yang berjudul "Hubungan Pengetahuan, Sikap BAB, Dan Kepemilikan Septic Tank Dengan Status ODF (Open Defecation Free) Di Kecamatan Candisari Kota Semarang”, menunjukkan bahwa terdapat hubungan antara sikap BAB dengan status ODF (Bebas Buang Air Besar Sembarangan) dari hasil uji statistik didapatkan bahwa nilai $p=0,000$ (11). 


Hal ini harus mendapat
perhatian dari desa. Desa dapat
membuat perarem / aturan
mengenai larangan buang air besar
sembarangan, dan disertai dengan
sanksi bila ada yang melanggar.
Selain itu, masyarakat desa bisa
juga membentuk arisan jamban
bagi masyarakat yang belum
memiliki jamban, sehingga
nantinya semua masyarakat
memiliki jamban.

\section{SIMPULAN DAN SARAN}

\section{Simpulan}

Terdapat hubungan antara pengetahuan $(\mathrm{p}=0,000)$ dan sikap $(\mathrm{p}=0,000)$ dengan status Bebas Buang Air Besar Sembarangan di desa Ambengan, Kecamatan Sukasada, Kabupaten Buleleng.

\section{Saran}

Saran yang dapat disampaikan yaitu bagi pihak Puskesmas Sukasada 2 melalui sanitarian agar melaksanakan penyuluhan mengenai pemanfaatan jamban, dampak dari perilaku BABS serta ODF (Open Defecation Free) atau Bebas Buang Air Besar Sembarangan. Bekerjasama dengan lintas sektor dan melakukan kegiatan advokasi untuk bisa mewujudkan status ODF (Open Defecation Free) atau Bebas Buang Air Besar Sembarangan. Untuk desa disarankan membuat perarem / aturan mengenai larangan buang air besar sembarangan dan disertai dengan sanksi bila ada yang melanggar. 


\section{DAFTAR PUSTAKA}

1. Permenkes RI. Sanitasi Total

Berbasis Masyarakat. (2014).

2. Zulfiherwindo. Analisis

pelaksanaan pilar pertama

STBM di wilayah kerja

Puskesmas Kampung Dalam

Kecamatan V Koto Kampung

Dalam Kabupaten Padang

Pariaman. (2016).

3. Notoatmodjo, S. Promosi

Kesehatan Teori dan Aplikasi.

(Rineka Cipta, 2010).

4. Murwati. Faktor HOST dan

Lingkungan Yang

Mempengaruhi Perilaku

Buang Air Besar

Sembarangan (Open

Defecation). (Universitas

Diponogoro, 2012).

5. Kementerian Kesehatan.

Pedoman Pelaksanaan Teknis

STBM. (2012).

6. Pemkab Buleleng. Konsep

Dasar Open Defecation Free

$(O D F)$. (2018).

7. Kementrian Kesehatan. STBM

Review. (2018).

8. Sugiyono. Metode Penelitian

Kuantitatif Kualitatif dan

$R \& D$. (Alfabeta, 2012).

9. Pradnyana. Hubungan
Pengetahuan Dan Sikap

Dengan Perilaku Perawat

Dalam Pengelolaan Sampah

Medis Di Rumah Sakit

Daerah Mangusada

Kabupaten Badung. Kesehat.

Lingkung. 10, 72-78 (2020).

10. Notoatmodjo, S. Promosi

Kesehatan dan Perilaku

Kesehatan. (Rineka Cipta,

2012).

11. Sukma, H. Hubungan

Pengetahuan, Sikap BAB,

Dan Kepemilikan Septic Tank

Dengan Status ODF (OPEN

DEFECATION FREE) Di

Kecamatan Candisari Kota

Semarang. Univ. Diponogoro

(2018). 